\title{
Aquatic biota in hot water: thermal gradients in rheocrene hot spring discharges as analogues for the effects of climate warming
}

\author{
Peter M. Negus ${ }^{1,2, *}$, Jonathan C. Marshall ${ }^{1,3}$, Alisha L. Steward ${ }^{1,3}$, Glenn B. Mcgregor ${ }^{1}$ \\ and Ruth A. O'Connor ${ }^{4}$ \\ ${ }^{1}$ Department of Environment and Science, Ecosciences Precinct, GPO Box 5078, Brisbane, Queensland 4001, Australia \\ ${ }^{2}$ School of Earth and Environmental Sciences, University of Queensland, St Lucia, Queensland 4072, Australia \\ 3 Australian Rivers Institute, Griffith University, 170 Kessels Road, Nathan, Queensland 4111, Australia \\ ${ }^{4}$ Climate Change Institute, The Australian National University, Canberra, Australian Capital Territory, Australia
}

Received: 4 March 2020 / Accepted: 4 December 2020

\begin{abstract}
Hot springs are characterised by water temperatures above $36.7^{\circ} \mathrm{C}$. Temperature decreases with distance in flow away from spring vents; this natural gradient provides a unique opportunity to investigate the influence of water temperature on aquatic biota. This study investigated the relationship between water temperature and the aquatic invertebrates and benthic diatoms in outflows from a hot spring complex in tropical north Queensland, Australia. Water temperature ranged from $62.7^{\circ} \mathrm{C}$ at the vents to $26.0^{\circ} \mathrm{C}$ at the location furthest downstream. Richness of benthic diatoms and aquatic invertebrates increased linearly in response to decreasing temperature, with no species present in the hot vents. Multivariate analysis showed that both community assemblages had a response to the temperature gradient. A drop in aquatic invertebrate richness and a change in assemblage composition occurred between $40^{\circ} \mathrm{C}$ and $42{ }^{\circ} \mathrm{C}$, indicating a threshold at this temperature. The nearby Einasleigh River has experienced several contemporary peaks in water temperature over $40^{\circ} \mathrm{C}$, which corresponds to this threshold level. The relationships indicate that consistent increases in water temperature expected under climate change could decrease biological richness and precipitate changes in the aquatic invertebrate and benthic diatom taxa of tropical aquatic ecosystems.
\end{abstract}

Keywords: Thermophilic / rheocrene / thermal tolerance / crenobiology / travertine

\begin{abstract}
Résumé - Le biote aquatique d'eau chaude: les gradients thermiques dans les rejets des sources chaudes rhéocrènes comme analogues des effets du réchauffement climatique. Les sources chaudes sont caractérisées par des températures de l'eau supérieures à $36.70^{\circ} \mathrm{C}$. La température diminue avec l'éloignement des sources; ce gradient naturel offre une occasion unique d'étudier l'influence de la température de l'eau sur le biote aquatique. Cette étude a examiné la relation entre la température de l'eau, les invertébrés aquatiques et les diatomées benthiques dans les flux sortants d'un complexe de sources chaudes dans le nord tropical du Queensland, en Australie. La température de l'eau variait de $62.7^{\circ} \mathrm{C}$ à la source à $26.0^{\circ} \mathrm{C}$ à $1^{\prime}$ 'endroit le plus en aval. La richesse des diatomées benthiques et des invertébrés aquatiques a augmenté de façon linéaire en réponse à la baisse de la température, aucune espèce n'étant présente dans les sources chaudes. Une analyse multivariée a montré que les deux assemblages de communautés réagissaient au gradient de température. Une baisse de la richesse des invertébrés aquatiques et un changement dans la composition des assemblages se sont produits entre $40{ }^{\circ} \mathrm{C}$ et $42{ }^{\circ} \mathrm{C}$, indiquant un seuil à cette température. La rivière Einasleigh toute proche a connu plusieurs pics contemporains de température de l'eau supérieurs à $40^{\circ} \mathrm{C}$, ce qui correspond à ce niveau seuil. Les relations indiquent que les augmentations constantes de la température de l'eau prévues dans le cadre du changement climatique pourraient diminuer la richesse biologique et précipiter des changements dans les taxons d'invertébrés aquatiques et de diatomées benthiques des écosystèmes aquatiques tropicaux.
\end{abstract}

Mots-clés : Thermophilique / rhéocrène / tolérance thermique / crénobiologie / travertine

\footnotetext{
*Corresponding author: peter.negus@des.qld.gov. au
} 


\section{Introduction}

Water temperature regimes in freshwater ecosystems vary temporally and spatially due to the influence of shading, convective heat exchange with the air, habitat morphology and characteristics of the water (Vannote and Sweeney, 1980; Morrill et al., 2005). In addition to these natural factors anthropogenic activities such as riparian tree clearance, water releases from dams and weirs, discharges from industry and climate change add complexity and can create unpredictability in water temperature regimes (Rutherford et al., 2004; Morrill et al., 2005; Taniwaki et al., 2017). Freshwater ecosystems are also predicted to be sensitive to climate change, due to its effects on water temperature, aquatic primary production, dissolved oxygen concentrations and litter decomposition (Durance and Ormerod, 2009; Patrick et al., 2019). In particular, water temperatures in freshwater ecosystems are predicted to increase with some records indicating changes have already occurred (Chessman et al., 2009; Durance and Ormerod, 2009; Settele et al., 2014). However, much of the information on climate change and ecosystem relationships to water temperature are based on modelling, which has high levels of uncertainty due to the complexity of aquatic ecosystems (Arismendi et al., 2014; Settele et al., 2014). Validation of biotic responses to elevated temperatures by monitoring ecosystem responses is one way to improve confidence in modelled predictions (Settele et al., 2014).

Investigation of the potential ecological responses to any stressor, such as temperature, can be undertaken by laboratory or field experiments or by field observation of ecosystem responses along a gradient of stressor levels (Dobbie and Negus, 2013). Field investigations of biological responses to changing water temperatures are limited and more research has been recommended, particularly for tropical streams where the sensitivity of aquatic ecosystems to water temperature stress associated with predicted climate change is likely to be high (Settele et al., 2014; Taniwaki et al., 2017). Sensitivity of tropical streams to changing water temperatures is due their naturally higher water temperatures, low seasonal variation in temperature, high amounts of organic matter and higher biodiversity compared to temperate streams (Settele et al., 2014; Taniwaki et al., 2017).

All organisms have a temperature range within which they maintain optimal growth, reproduction and activity (Vannote and Sweeney, 1980; Ward and Stanford, 1982; Dallas, 2008). Aquatic organisms respond to water temperature physiologically and behaviourally and will be absent from systems outside of their temperature tolerance. At the upper extreme, few multicellular aquatic organisms survive above $40^{\circ} \mathrm{C}$ and none of these species are known to survive at $50{ }^{\circ} \mathrm{C}$. Only algae and microbes survive water temperatures above $50^{\circ} \mathrm{C}$ (Glazier, 2012). These algae and microbes are hyperthermophiles and have been reported to survive temperatures above $80^{\circ} \mathrm{C}$ (Stetter, 1999).

Wetlands associated with outflowing water from springs (i.e. rheocrene springs), particularly those associated with artesian groundwater, are often characterised by their constancy in environmental conditions including water temperature (also ionic composition, turbidity, $\mathrm{pH}$, nutrient concentrations and electrical conductivity) (McGregor and Rasmussen, 2008; Glazier, 2012). The constancy in water temperature results in many spring species having narrow ranges of thermal tolerance (McGregor and Rasmussen, 2008). For example, invertebrate richness has a significant negative relationship with water temperature in many spring ecosystems and the thermal tolerance limits of colonising taxa is likely to be the factor limiting the presence of specific taxa (Glazier, 2012). Rheocrene springs are those that have water discharges that form flowing channels, and environmental conditions, in particular water temperature, change with distance downstream from the source vent (Spitale et al., 2012a, 2012b). Therefore, with changing environmental conditions occurring along the flow paths of rheocrene spring outflow channels, their aquatic biota is expected to also change.

Spring wetlands can be classified by water temperature: ambient springs, which are those below or near mean annual air temperature (Glazier, 2012; Cantonati et al., 2015); thermal springs, which have higher temperatures than mean annual air temperature; and hot springs, which are those with a minimum temperature of $36.7^{\circ} \mathrm{C}$, the average healthy human body temperature (Pentecost et al., 2003; McGregor and Rasmussen, 2008; Glazier, 2012; Cantonati et al., 2015). Thermal or hot rheocrene spring ecosystems therefore provide a unique opportunity to investigate the influence of increasing water temperatures on aquatic biota without the potentially confounding influence of dispersal. This study utilises the natural thermal gradient of a rheocrene, hot spring complex in tropical Northern Queensland, Australia, to identify and characterise changes in aquatic invertebrates and benthic diatoms associated with increasing water temperature. This represents a natural analogue for the ecological effects of increasing water temperature resulting from climate change and contributes much-needed empirical evidence of the aquatic ecosystem responses to increasing temperature.

\section{Material and methods}

\subsection{Study site}

Talaroo hot springs complex is situated in the Einasleigh River catchment in North Queensland, Australia (Latitude: $18^{\circ} 07^{\prime} 09^{\prime \prime} \mathrm{S}$; Longitude: $143^{\circ} 57^{\prime} 40^{\prime \prime} \mathrm{E}$ ) (Fig. 1; McGregor and Sendall, 2017). The complex is a terraced mound spring composed of travertine with several active vents discharging water at temperatures up to $62.7^{\circ} \mathrm{C}$ (McGregor and Sendall, 2017). This is a rheocrene spring as the water flowing from its vents cascades over the mound to wetlands and three watercourses that discharge into the Einasleigh River approximately $220 \mathrm{~m}$ away. The mound is characterised by the colonisation of bacteria on the wetted travertine that forms conspicuous yellow/green biofilms, cyanobacteria of several forms including floating colonies and stromatolites that form terraces and barriers to the flow, and other aquatic microbial structures (Fig. 2; McGregor and Sendall, 2017).

The three flowing watercourses meander through initially palustrine wetlands before flowing through grasslands on a relatively flat floodplain area to the banks of the Einasleigh 


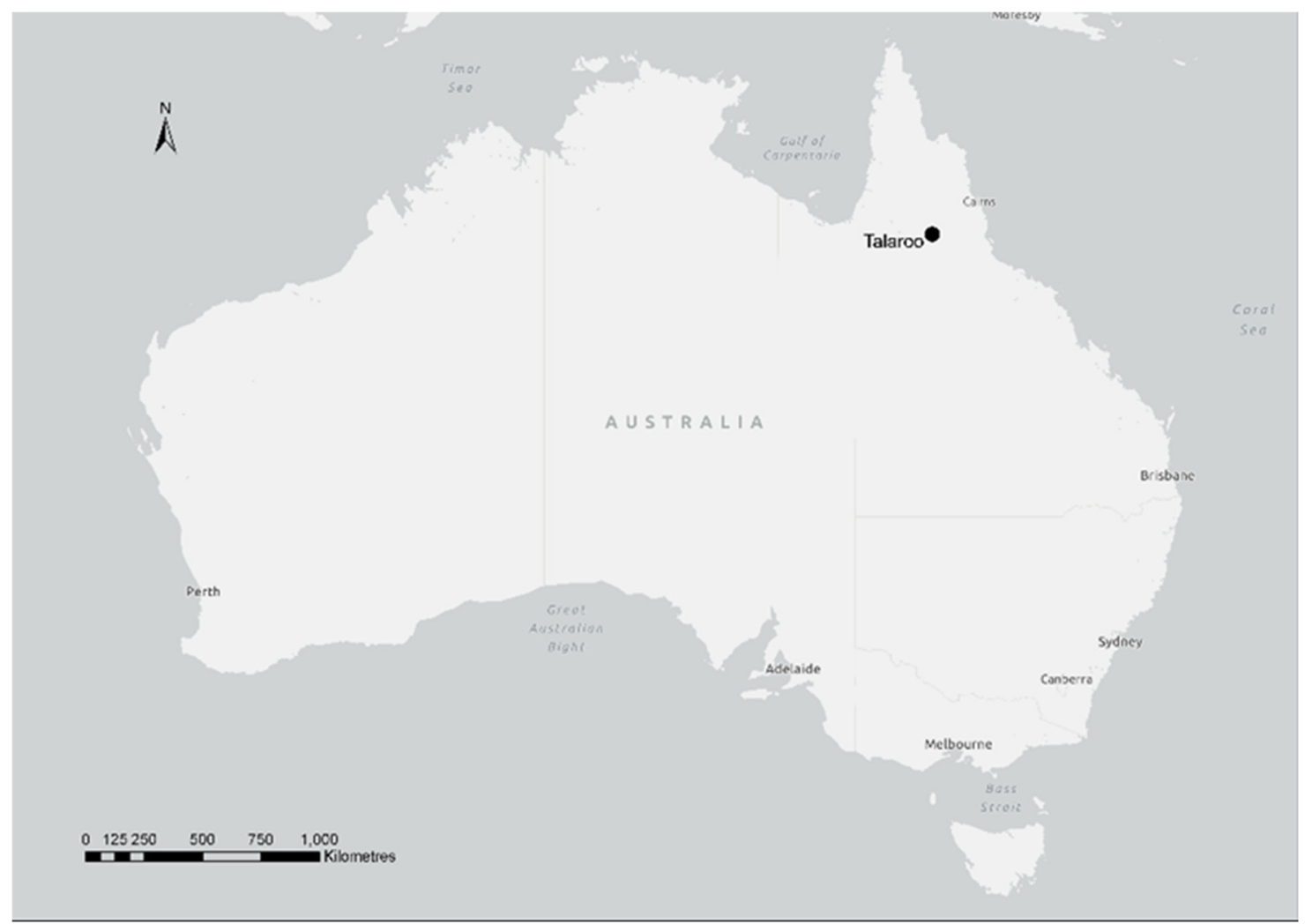

Fig. 1. Location of Talaroo Station (and springs) in Queensland, Australia.

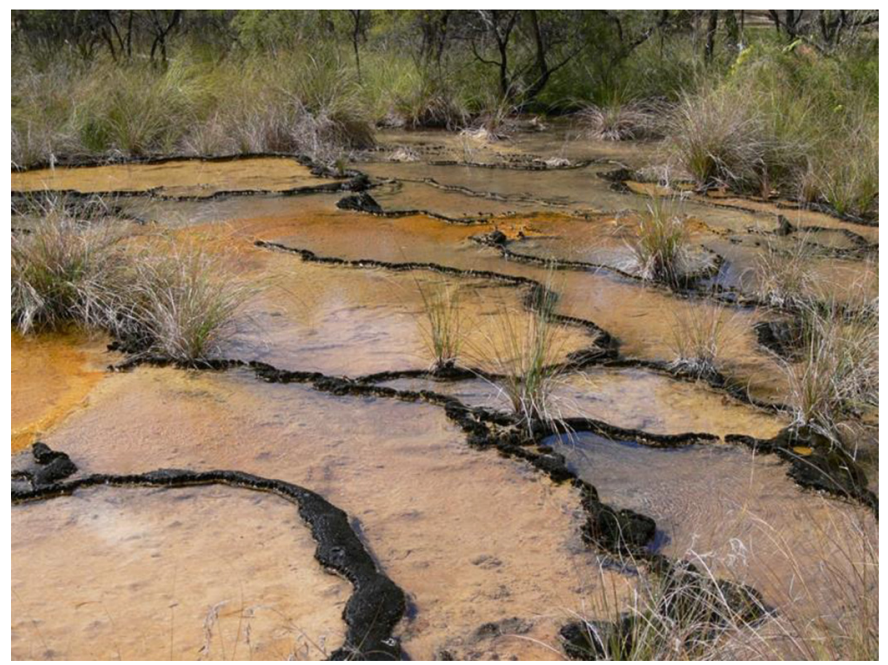

Fig. 2. Flow off the Talaroo springs travertine mound, which is characterised by yellow/green biofilms of bacteria and terraces of cyanobacterial stromatolites.

River. Wallaby Creek has the highest discharge of the three watercourses and has a variable wetted width up to $3 \mathrm{~m}$ and water depth up to $20 \mathrm{~cm}$ (Fig. 3). Wallaby Creek flows in a northerly direction away from the mound and through a palustrine wetland composed of paperbark trees (Melaleucas), herbs, grasses and sedges. Extensive patches of the endangered salt-pipe wort (Eriocaulon carsonii F. Muell.) are interspersed throughout the wetland. Wallaby Creek flows through this wetland area for approximately $200 \mathrm{~m}$ before entering the grassy floodplain area. Goodaba Creek emanates from an open water area on the northeast edge of the mound. Goodaba Creek has a narrow wetted width and higher water velocity compared to Wallaby Creek, it flows through a treed area, and is thickly lined with an undergrowth of herbs and grasses. A third creek, Pool Creek, results from the overflow out of a man-made swimming pool on the eastern side of the mound. Pool Creek is shallow with less than $10 \mathrm{~cm}$ water depth but has a wetted width up to $3 \mathrm{~m}$.

Eleven locations were sampled for aquatic invertebrates during 2013; of these sites ten were also sampled for environmental attributes. These locations were situated along the three outflow watercourses (Wallaby Creek, Goodaba Creek and Pool Creek) and a bacterial fan on the travertine mound. Environmental attributes collected during this initial sampling were used to assess if there were any confounding variables to a water temperature gradient. A second sampling occasion during 2015 collected further aquatic invertebrate and water temperature samples from the six locations along Wallaby Creek, the largest watercourse.

\subsection{Water physio-chemical measurements}

During May 2013 water temperature, water depth, stream width, water velocity, conductivity, total dissolved solids and $\mathrm{pH}$ was measured at each location except for the spring outflow 

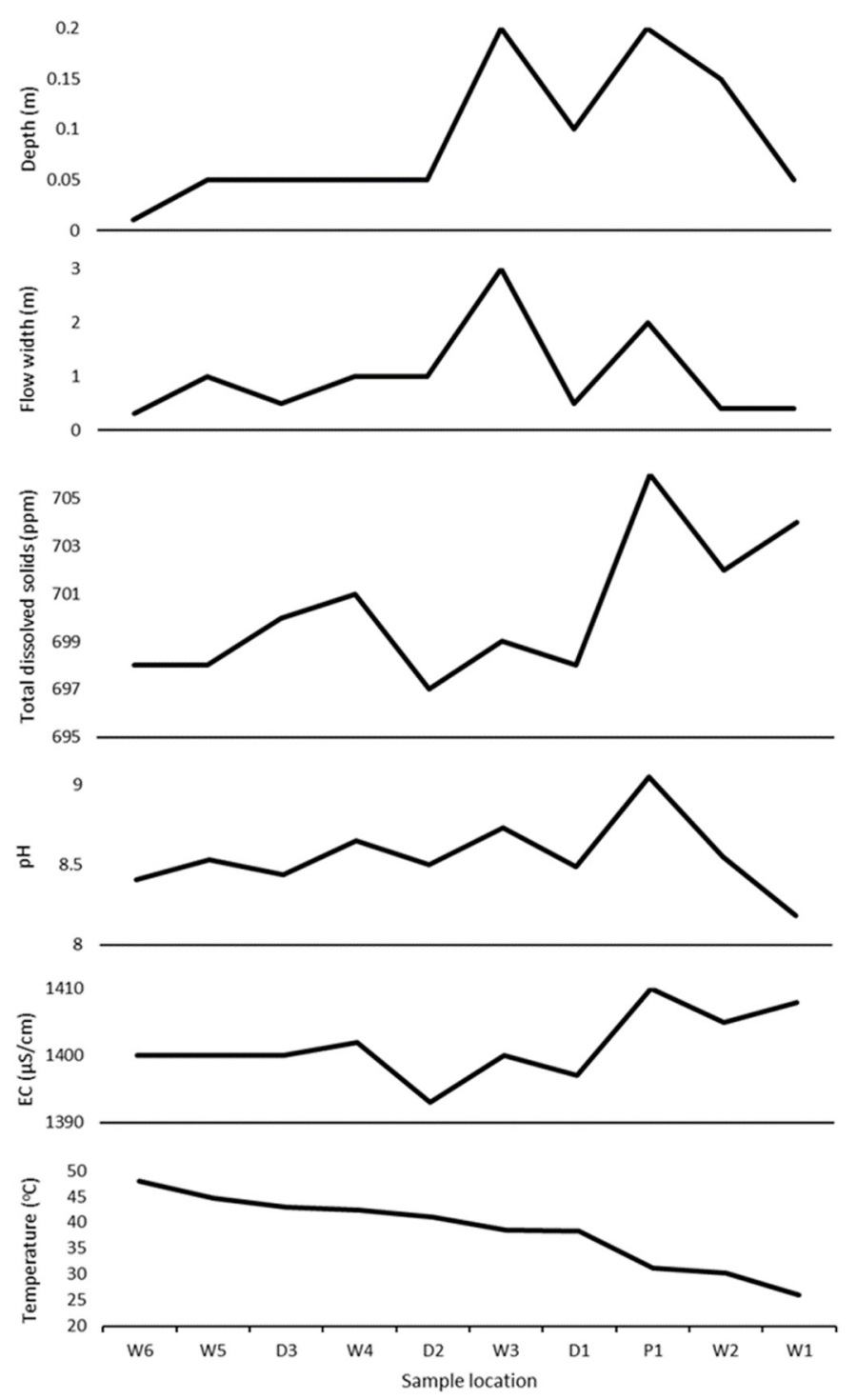

Fig. 3. Comparison plots of environmental variables from sites sampled during 2013. No measured environmental variable is collinear or consistent with the gradient in water temperature. W1-6 denotes locations on Wallaby Creek; D1-3 denotes locations on Dunny Creek; P1 denotes the location sampled on Pool Creek.

fan at the same time as the collection of biological samples. During May 2015, measurements were limited to water temperature at the six locations along Wallaby Creek. All measures of water temperature, conductivity, total dissolved solids, and $\mathrm{pH}$ were taken using a Hanna multi parameter meter (HI98129) and water depth and width were recorded using a measuring tape. All sampling was undertaken between the hours of $2 \mathrm{pm}$ and $5 \mathrm{pm}$.

\subsection{Aquatic invertebrates}

Samples of aquatic invertebrate specimens were collected at each location using a $250-\mu \mathrm{m}$ mesh triangular dip net. All microhabitats (e.g. macrophyte beds, edges, leaf packs) possible were targeted for sampling using multiple short sweeps (approximately $50 \mathrm{~cm}$ in length) of the net along a total stream distance of $5 \mathrm{~m}$. This technique aims to obtain specimens of each invertebrate group present at the location defined by the $5 \mathrm{~m}$ stream length (including species living in or on the sediment like snails and species swimming at or near the water surface such as true bugs and beetles). The sample contents collected in the net were then transferred into buckets for live processing. At the spring outflow fan, the depth of water and the fragile nature of the travertine mound at this location prevented a dip net being used. Sampling here used insitu 'picking', which involved handpicking specimens using tweezers and a plastic pipette, directly from the shallow flowing habitat on the hard travertine surface of the spring mound.

A portion of sample from a bucket was tipped into a white tray, and 'picked' through using forceps and pipettes to obtain specimens of each invertebrate taxon available. The tray was emptied and refilled from the bucket until the entire sample was examined. The picked invertebrates were curated in labelled plastic vials, using $100 \%$ ethanol for transportation to the laboratory.

Picked invertebrate specimens from the curated vials were identified in the laboratory using a stereomicroscope. Picked specimens were identified to the taxonomic level of family, except for Chironomidae, which were identified to subfamily, and Acarina, Copepoda, Cladocera, Ostracoda, Nematoda, Oligochaeta, and Collembola, which were identified no further. Presence of invertebrate taxa were recorded for statistical analyses (Supplementary Tab. S1).

\subsection{Benthic diatoms}

Benthic diatoms were collected by scraping submerged surfaces (e.g. woody debris, rocky substrate, and aquatic vegetation) and by pipetting soft surface sediments at each location. The material collected from each location was combined to form a composite sample for each location and preserved with $100 \%$ ethanol. This sampling protocol provides a good representation of the sample location (Negus et al., 2019).

Diatom samples were prepared using a modified version of Battarbee et al. (2001). This included 2-3 h treatments in 10\% $\mathrm{HCl}$ to remove carbonates and $10 \% \mathrm{H}_{2} \mathrm{O}_{2}$ to remove organic matter. Following each treatment, samples were washed three times in distilled water with a minimum of $12 \mathrm{~h}$ between washes to allow diatom valves to settle. Aliquots from the prepared slurries were dried on coverslips, which were then inverted and mounted on permanent slides using Naphrax ${ }^{\circledR}$ mounting medium. Diatoms were identified to species level where possible up to $1500 \times$ magnification on a Nikon Eclipse E600 with differential interference contrast optics and using a variety of taxonomic sources (e.g. Foged, 1978; Krammer and Lange-Bertalot, 1986, 1988, 1991a, 1991b; Sonneman et al., 2000).

Diatom taxa that could not be identified to known species were given descriptive epithets or affinities where they had strong affinities to known species but did not completely fit the description. Diatom counting was undertaken along transects across the coverslip with a minimum of 300 valves, or 


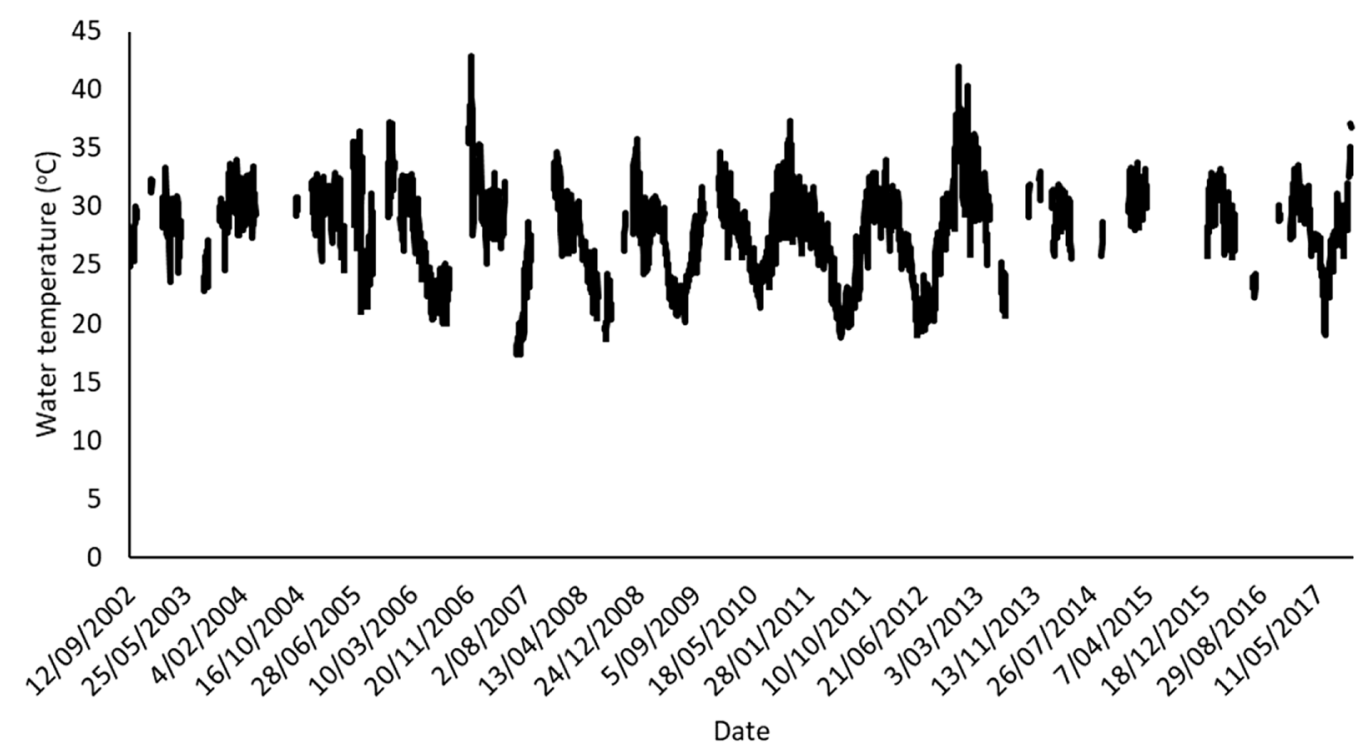

Fig. 4. Maximum daily water temperature at the Einasleigh River gauging station (Latitude: $18^{\circ} 30^{\prime} 00.6^{\prime \prime} \mathrm{S}$; Longitude: $144^{\circ} 05^{\prime} 45.1^{\prime \prime} \mathrm{E}$ ). The average maximum daily temperature is $28.1^{\circ} \mathrm{C}$.

a maximum of ten transects, counted from each slide. Raw diatom counts were converted to relative abundance prior to statistical analysis (Supplementary Tab. S2).

\subsection{Data analyses}

Diatom relative abundance was arcsine square root transformed to stabilise variance in the dataset (Zar, 1998) and the raw presence or absence of aquatic invertebrates at each location was compiled for statistical analyses. Analyses were undertaken using gradient-style assessments of the relationships between temperature and the aquatic invertebrate community structure and temperature and the benthic diatom community structure. Taxonomic richness for both aquatic invertebrate and diatom communities at each location was calculated as a simple measure of diversity and used in the univariate statistical analyses.

A correlation analysis on the environmental variables collected during 2013 was undertaken to determine if there were factors collinear with water temperature that were likely to confound further analyses between water temperature and the biota. The simple linear relationships between environmental variables and water temperature and between water temperature and taxonomic richness were undertaken using the default $\mathrm{lm}$ function in the $\mathrm{R}$ statistical program ( $\mathrm{R}$ Core Team, 2017). Correlations which had an adjusted $R^{2}>|0.6|$ and $P<0.05$ were considered to represent strong and significant relationships. Significant relationships between environmental variables and water temperature would represent a potential confounding factor in further analyses.

Multivariate statistical analyses were conducted to identify more complex relationships between the aquatic invertebrate and diatom assemblage composition and water temperature using functions in the 'vegan' (Oksanen et al., 2018) packages on the $R$ software platform ( $R$ Core Team, 2017). Both biological datasets were ordinated using a
Bray-Curtis dissimilarity matrix and presented using the metaMDS ordination function (non multi-dimensional scaling; nMDS) with a dummy taxon included (with a presence value of 1 for the invertebrate dataset; and a value of 0.01 relative abundance for the diatom dataset) to account for locations with zero taxa (Clarke et al., 2006). The envfit procedure was used to correlate water temperature with the dissimilarity matrices (Oksanen et al., 2018). To check for more complex relationships the ordisurf function (Oksanen et al., 2018) was used to fit a general additive model (GAM) of water temperature in the ordination space for both biological datasets. The GAM relationships were plotted on the two-dimensional ordination space for presentation and interpretation. Individual taxa significantly correlated with both ordinations were also identified using the envfit function (Oksanen et al., 2018).

\section{Results}

A maximum water temperature of $62.7^{\circ} \mathrm{C}$ was measured at a spring vent and this contrasts to that of the recorded (longterm) maximum daily water temperature in the local riverine ecosystem at $42.9^{\circ} \mathrm{C}$ measured at a nearby river gauging station (Einasleigh River at Einasleigh, Queensland Government unpublished data) over 15 yrs from 2002 to 2017 (Fig. 4). Water temperatures along the spring outflow watercourses ranged from 47.9 to $26.0^{\circ} \mathrm{C}$ (Fig. 3). This lower temperature is comparable to the long-term $28.1^{\circ} \mathrm{C}$ average daily maximum from the Einasleigh River gauging station. None of the potentially confounding water chemistry or habitat attributes was significantly correlated or consistent with the gradient of water temperature (Fig. 3). The cooling of water to an equivalent with air temperature as it flowed away from the mound allowed for a gradient of water temperature (Fig. 3) to be analysed with changes in invertebrate and benthic diatom community assemblages. 


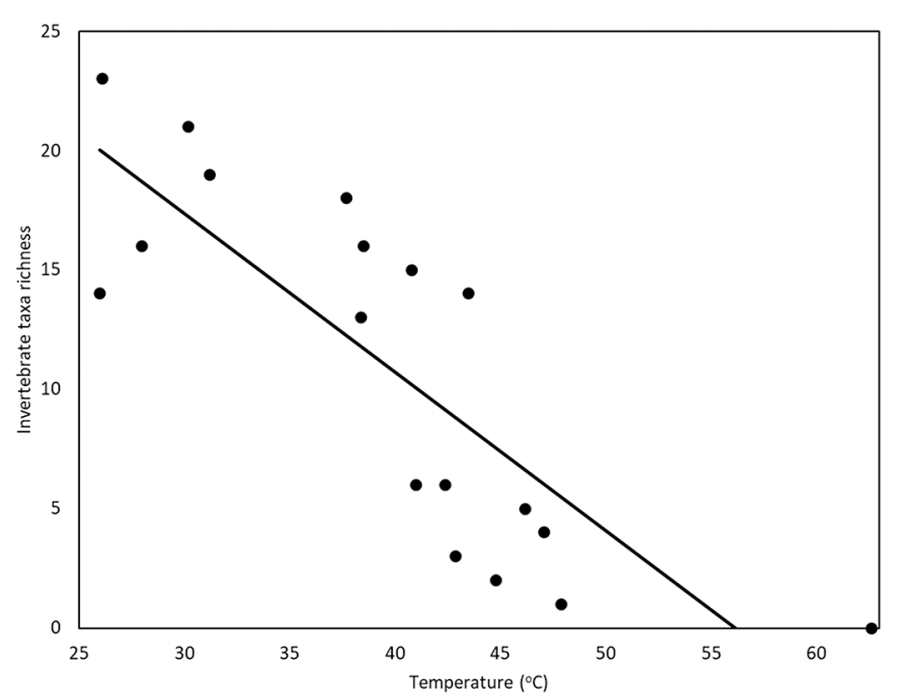

Fig. 5. Regression plot of invertebrate taxa richness with temperature (Adjusted $\mathrm{R}^{2}=0.6478 ; P=0.00003$ ).

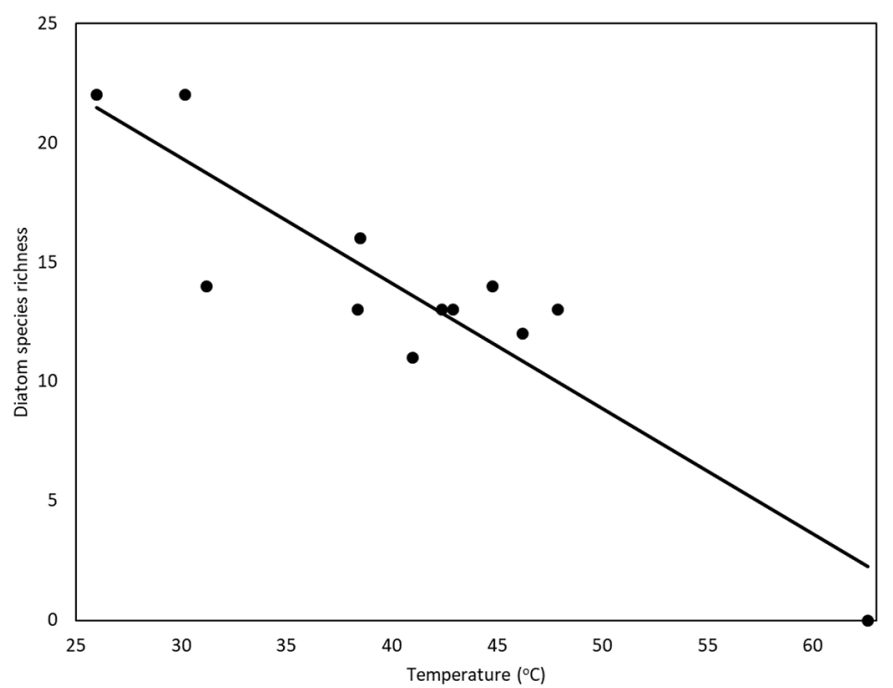

Fig. 6. Regression plot of benthic diatom species richness with temperature (Adjusted $\mathrm{R}^{2}=0.7964 ; P=0.00006$ ).

Forty-one aquatic invertebrate taxa and 88 diatom species were recorded across all samples with invertebrate taxon richness ranging between 0 and 21 and diatom richness ranging between 0 and 22. Few invertebrate taxa were collected above $45^{\circ} \mathrm{C}$ and only one (Ostracoda) was collected at the hottest site immediately downstream from Wallaby vent $\left(47.9^{\circ} \mathrm{C}\right)$. No invertebrates were collected from the vent area, which had a temperature of $62.2^{\circ} \mathrm{C}$. Diatom species richness was greater than 10 at all locations up to those at $47^{\circ} \mathrm{C}$, and as with invertebrates there were no individuals collected from the hot vent area.

The linear relationships between water temperature and richness of invertebrate taxa and benthic diatom species were significant (Figs. 5 and 6). The distinct drop in the taxonomic richness of aquatic invertebrates from 15 to 5 between 40 and $42{ }^{\circ} \mathrm{C}$ represents what may be a water temperature threshold. The significant linear relationship with benthic diatom richness

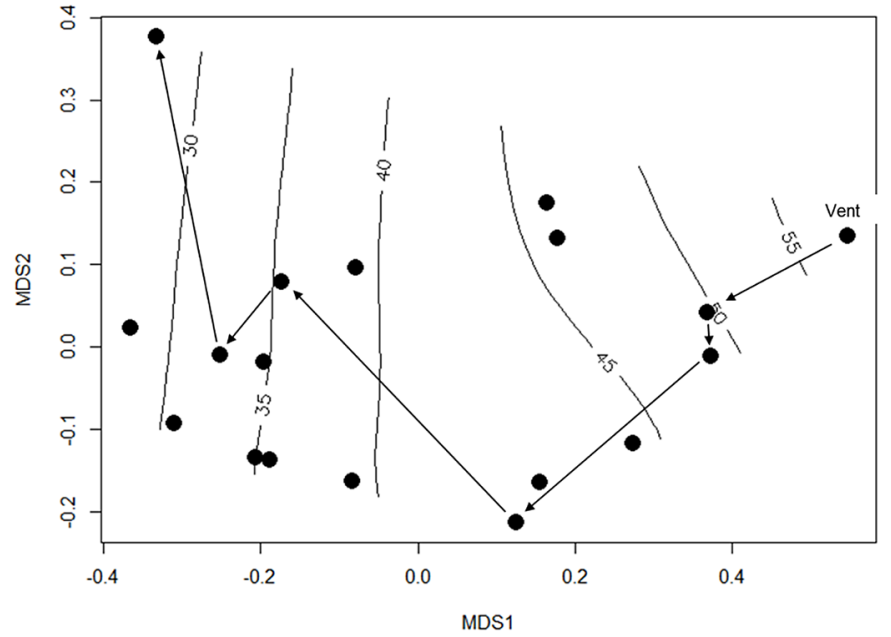

Fig. 7. Ordination of aquatic invertebrate samples and water temperature contours $\left(\right.$ as $\left.^{\circ} \mathrm{C}\right)$. Arrows show downstream longitudinal samples taken from Wallaby Creek in 2013 (stress $=0.12$ ).

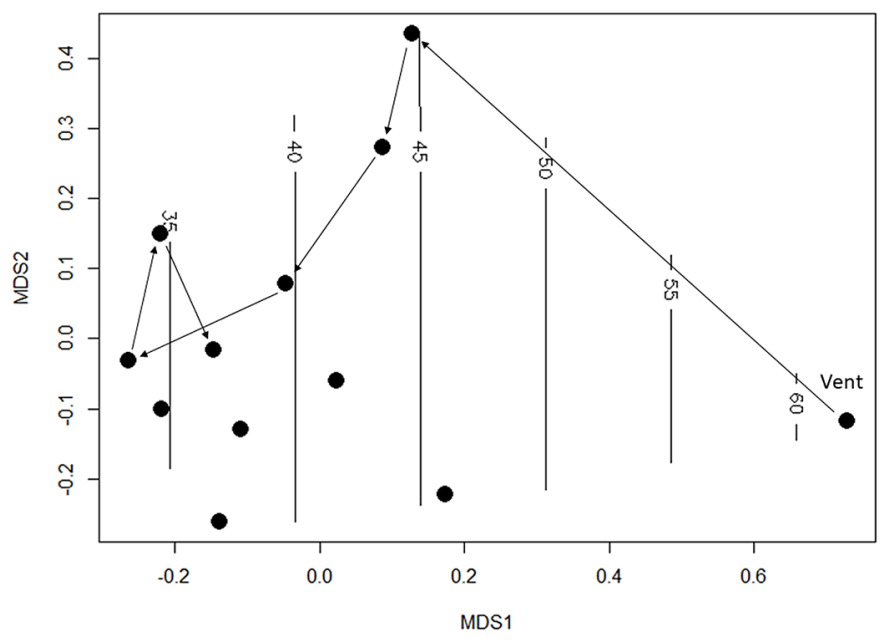

Fig. 8. Ordination of benthic diatom samples and water temperature contours $\left(\right.$ as $\left.{ }^{\circ} \mathrm{C}\right)$. Arrows show downstream longitudinal samples taken from Wallaby Creek in 2013 (stress $=0.11$ ).

did not indicate a similar threshold but richness did drop to zero between the $48^{\circ} \mathrm{C}$ water temperature and the highest water temperature within the vent $\left(62.2^{\circ} \mathrm{C}\right)$.

The ordinations of invertebrate taxa and benthic diatom species further supported the simple linear relationships with temperature and richness. This is indicated initially by the samples taken from locations on Wallaby Creek showing a distinct downstream pattern along axis 1 (Figs. 7 and 8). The linear relationships between temperature and both ordination patterns were also significant (invertebrate ordination: $\mathrm{r}^{2}=0.79, P=0.001$; benthic diatom ordination: $\mathrm{r}^{2}=0.77$, $P=0.004)$. Generalised additive modelling of water temperature using ordination of the aquatic invertebrate community showed that the relationship was more complex with a distinct change to linearity between $40^{\circ} \mathrm{C}$ and $45^{\circ} \mathrm{C}$ (temperature contour lines in Fig. 7) that matches the threshold observable in the linear relationship in Fig. 5. 


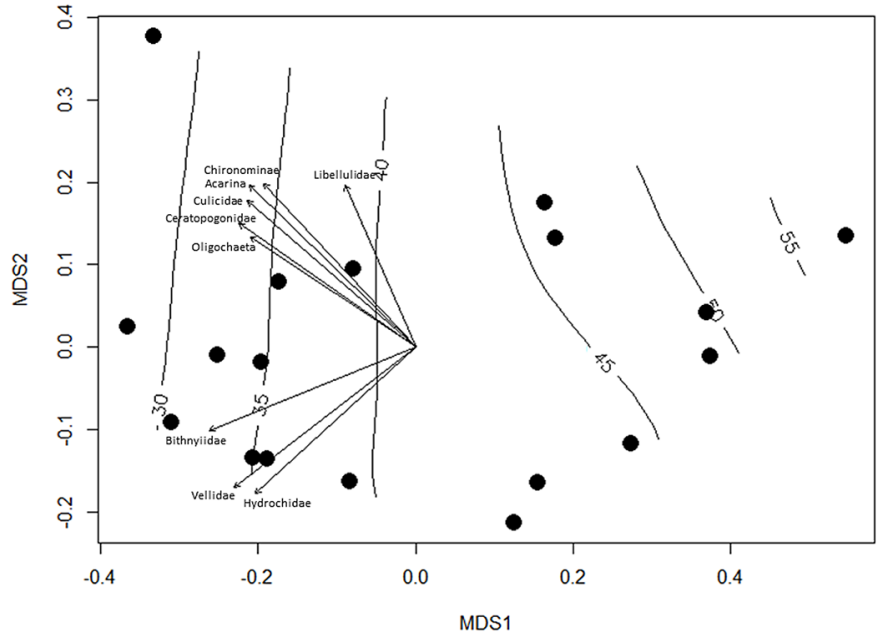

Fig. 9. Vectors of significant invertebrate species correlated with the ordination of aquatic invertebrate samples. The water temperature contours are also included for interpretation (

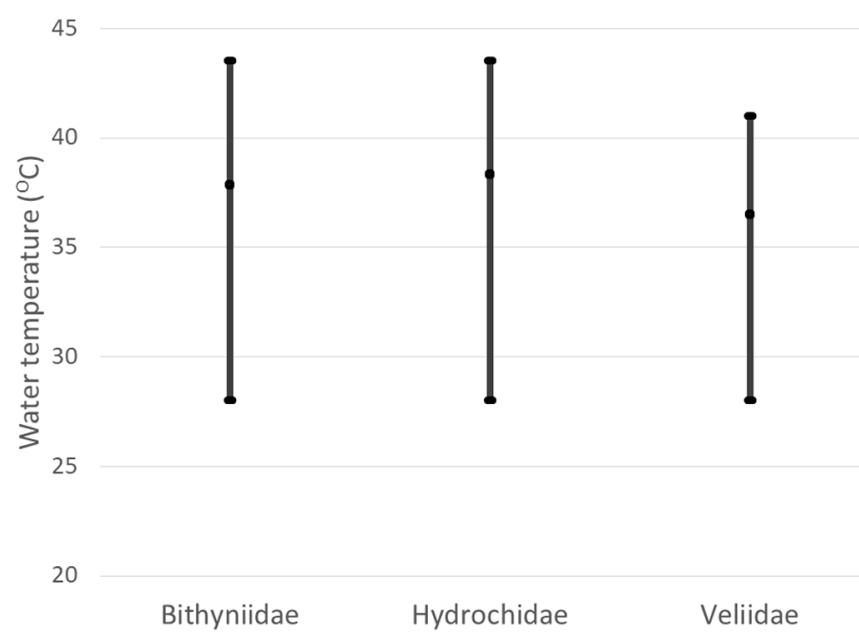

Fig. 10. The water temperature ranges (maximum and minimum) of the invertebrate taxa that were significantly correlated with the community assemblage ordination. Central points represent mean values.

The invertebrate species, which were significantly correlated with the ordination pattern $(P<0.05)$, are indicated by the vectors presented in Figure 9. Acarina, Chironominae, Libellulidae, Culicidae, Ceratopogonidae and Oligochaeta have vectors that are not aligned with the temperature contours above $40{ }^{\circ} \mathrm{C}$ and are likely explaining variation in the ordination as a result of other (unmeasured) explanatory variables. Bithyniidae, Veliidae and Hydrochidae show vectors aligned with the temperature contours above $40{ }^{\circ} \mathrm{C}$ indicating that they are most likely related to water temperature. These three taxa were collected at locations with moderate temperatures (i.e. below $44{ }^{\circ} \mathrm{C}$; Fig. 10). Few taxa were caught at locations with water temperatures above $45^{\circ} \mathrm{C}$ with only Gerridae, several Dipteran taxa, a small unidentifiable Anisopteran, an Oligochaete, and a Hydrophilidae found. Ostracoda that were recorded as abundant and obvious even in the hotter locations sampled.

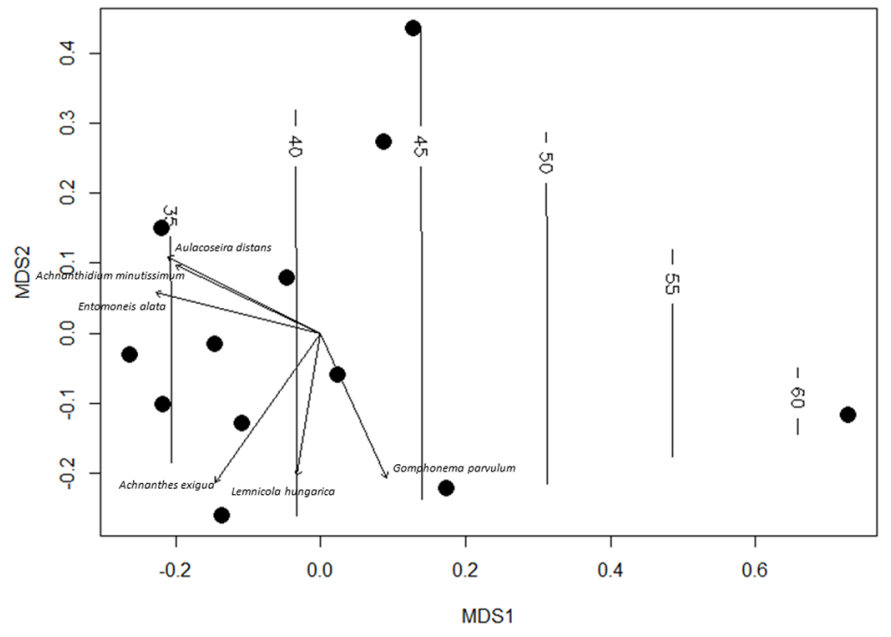

Fig. 11. Ordination of benthic diatom samples and water temperature contours in ordination space with vectors of benthic diatom species significantly correlated with the ordination $($ stress $=0.11)$.

Generalised additive modelling of water temperature using ordination of the benthic diatom community assemblage confirmed that the relationship was linear. Six benthic diatoms species were significantly correlated to the ordination pattern (Fig. 11). The species Achnanthes exigua, Gomphonema parvulum and Lemnicola hungarica were aligned differently to the temperature gradient (i.e. temperature contours along the nMDS axis 1) while the species Achnanthidium minutissimum, Aulacoseira distans and Entomoneis alata were similarly aligned as the temperature gradient. However, none of these three species was present at locations with water temperatures above $43{ }^{\circ} \mathrm{C}$. Entomoneis alata was present at two locations at approximately $40^{\circ} \mathrm{C}$ and not present at the cooler locales (Fig. 12).

More than a third of the benthic diatom species were found to be present at localities with temperatures above $43{ }^{\circ} \mathrm{C}$. However, most of these species were found at low relative abundances and in only one location above this temperature. Three species (Brachysira brachysira, Diploneis parma, Lemnicola hungarica) had a high relative abundance at one location with water temperature above $43^{\circ} \mathrm{C}$. Rhopalodia musculus was present at most sites across the whole temperature gradient and was the only species consistently present at high relative abundances above $43^{\circ} \mathrm{C}$.

\section{Discussion}

Water temperature decreased relatively consistently over the distance from the spring vent to a point along the water flow in all watercourses where it becomes equivalent to ambient water temperature. This gradient of change was not confounded by other measured environmental variables. The aquatic invertebrate taxon richness and the benthic diatom species richness significantly increased with the decreasing water temperature gradient. Significant relationships between water temperature and the multivariate invertebrate and benthic diatom community assemblages were also identified. 

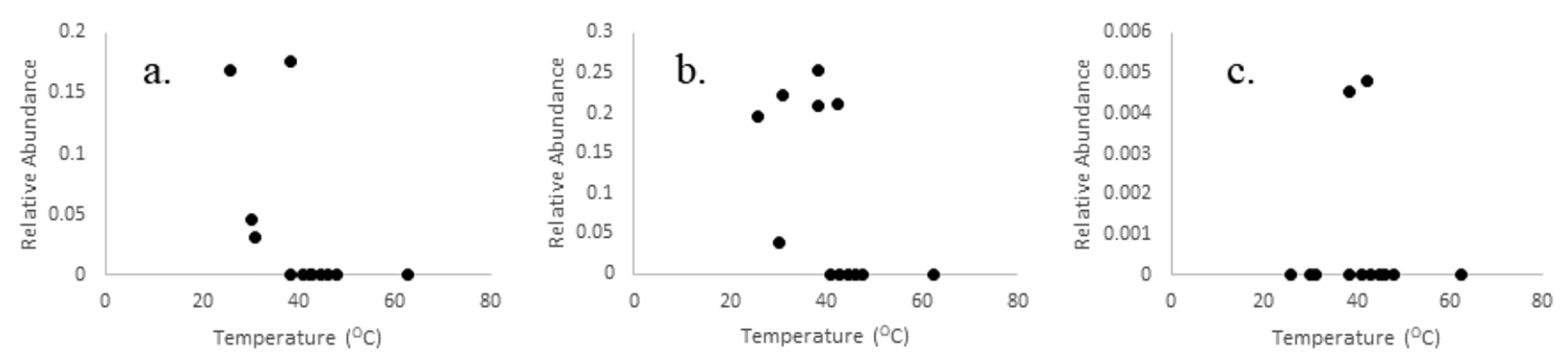

Fig. 12. Scatterplots of water temperature and the relative abundance of significant benthic diatom species aligned with modelled water temperature gradient in the benthic diatom ordination (a) Achnanthidium minutissimum; (b) Aulacoseira distans; and (c) Entomoneis alata.

\subsection{Benthic diatoms}

Many benthic diatom species were present at locations with water temperatures above $43^{\circ} \mathrm{C}$. However, few had high relative abundances and only Rhopalodia musculus was present at more than one of these hotter locations. All species present at the locations with hotter temperatures were also present at locations with low water temperatures and could therefore be considered eurythermal generalists in terms of their temperature sensitivity. The observation that many species were present in low abundances and at only one location highlights the potential problem of dispersal of dead frustules to extreme habitats rather than a measure of the diversity of the location. This has been identified as an issue when investigating the presence of thermophilic diatoms (Sterrenburg et al., 2007), but this is less likely in this rheocrene spring, where flow is more likely to disperse diatoms downstream, from hotter to cooler locations, than vice versa. While diatoms are common in travertine springs including thermal springs, the role of temperature in determining their community structure in these types of ecosystems is relatively unknown (Pentecost, 2005; Sterrenburg et al., 2007). Culturing experiments are recommended as a means to overcome this problem (Sterrenburg et al., 2007).

Rhopalodia musculus is potentially a thermophile as its relative abundance increases in the hotter localities. The autecology of this species and its varieties in Australia is relatively unknown and it can be collected in a wide variety of water types, but it is a common species of high conductivity and high pH waters (John, 2012, 2016) and has been given an Australian sensitivity score of 53 (out of a possible high of 100 ) indicating that it isn't highly sensitive to anthropogenic stresses (Chessman et al., 2007). Elsewhere, it is also known from brackish waters (Guiry, 2020). Further autecology studies on Rhopalodia musculus are needed to confirm its status as a thermophile.

\subsection{Invertebrates}

The aquatic invertebrate taxonomic groups collected across the spring complex were diverse, with several relatively rare or geographically restricted to spring ecosystems (e.g. aquatic snails of the family Bithnyiidae). This assemblage is largely comparable to the assemblages that are commonly collected from riverine ecosystems within the region except for some Decapoda and Mollusca (e.g. Atyiidae, Palaemonidae and Ancylidae; Queensland Government unpublished data), which were absent from spring samples. The invertebrate taxa that correlated with the thermal gradient were not limited to these rare and restricted taxa or to taxa with an expected sensitivity to temperature. Many of the groups could be considered habitat generalists (Kneitel, 2018) because they are insensitive to many habitat stressors, for example, water mites (Acarina), dragonflies (Odonata), mosquitoes (Culicidae) and midges (Chironominae and Tanypodinae), and therefore responsiveness to water temperature is likely to indicate that the spring invertebrate community will be significantly affected by increasing temperatures.

The non-linear relationship between the multivariate invertebrate community and water temperature indicates a potential temperature threshold where specific taxonomic groups are removed from the community assemblage as temperature increases. An upward swing of contours along axis 1 (MDS1) in the ordination space between $40^{\circ} \mathrm{C}$ and $42^{\circ} \mathrm{C}$ indicates a change in invertebrate community composition (Fig. 7). A distinct drop in aquatic invertebrate richness can also be observed at approximately the same temperature (Fig. 5). This suggests that water temperature above $40-42^{\circ} \mathrm{C}$ poses a limiting threshold to aquatic invertebrate assemblages in this region.

A maximum water temperature of $47.9^{\circ} \mathrm{C}$ was recorded at the sampling location closest to the spring vent. This temperature is outside of the biologically tolerable temperature range for invertebrates (sensu Glazier, 2012). It was therefore surprising to find invertebrates from several taxa at the locations over $45^{\circ} \mathrm{C}$. The adult Gerridae and Hydrophilidae have the ability to fly away from environmental conditions that are not favourable and so these are potential 'itinerants' at the hottest of locations, and likely to be using the hotter water for collecting food (such as dead invertebrates) and then moving to the margins of the flow where temperatures are cooler.

Dead adult dragonflies were conspicuous in the areas with the hottest water surrounding the spring vents (Fig. 13) and carbonate encrusted dragonfly adults were observed in the travertine (Fig. 14). These observations indicate that adults are regularly attempting to oviposit in the hot shallow waters and are overcome by hot temperatures and die. Adult dragonflies have been known to oviposit in unsuitable habitat and are therefore most likely to be in this area due to the presence of water and any eggs or nymphs at these hot locations may not survive (Foster and Soluk, 2004).

Ostracods were consistently collected across the temperature gradient in Wallaby Creek and Goodaba Creek, including the hottest locations. Thermophilic ostracods have previously 


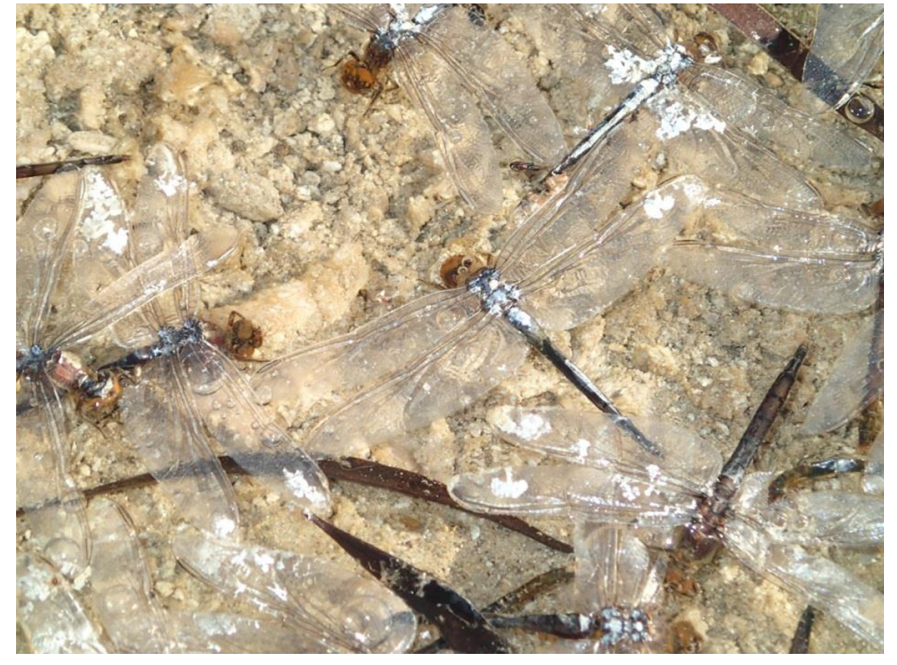

Fig. 13. Dead dragonfly adults in the hot water of the spring vents.

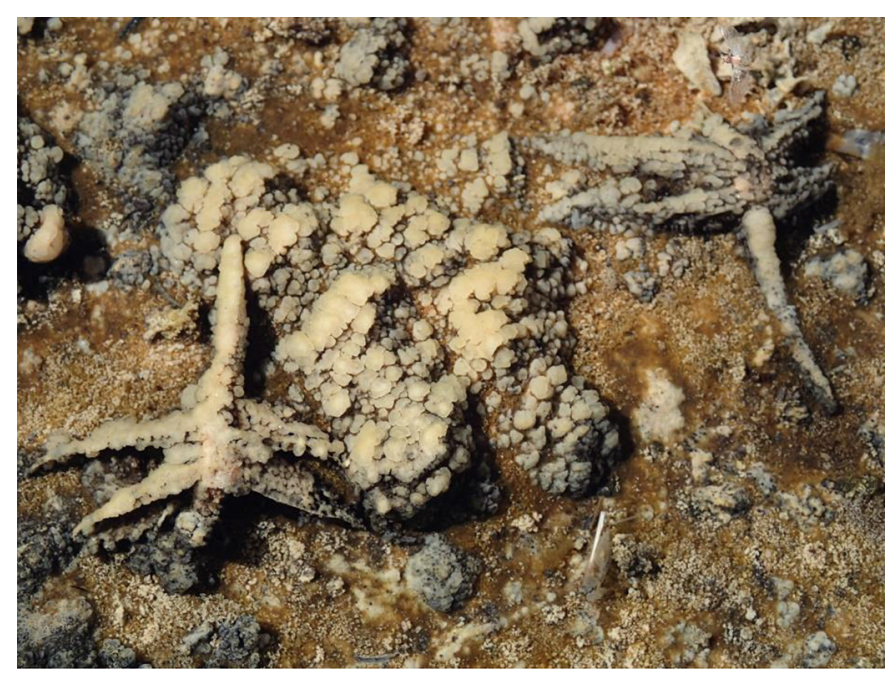

Fig. 14. Calcified adult dragonflies in travertine mound spring, Talaroo springs, North Queensland.

been found in hot springs with temperatures up to $50^{\circ} \mathrm{C}$ (Wickstrom and Castenholtz, 1985; De Jong et al., 2005). They are also common as fossils in travertine deposits (Pentecost, 2005) that are similar to the mound structure at Talaroo. Ostracod life history characteristics in unvegetated, bare hot springs are relatively unknown (Pentecost, 2005) and these specimens observed at Talaroo appear to be the first record of thermophilic ostracods from Australia.

There are few published papers on the feeding ecology of ostracods, but they are mostly generalist feeders, consuming detritus, algae, and dead animals (Karanovic, 2012). The thermophilic ostracods at Talaroo were consistently observed in the hottest areas of bare travertine to be voraciously feeding on dead insects that had succumbed to the hot water (see video in Supplementary information). It is likely there were multiple species of ostracod collected along the gradient of water temperature that were not differentiated at the level of taxonomic identification used in this study, and this topic is something to be investigated further.

\subsection{Effects of climate change}

Water temperature increase (in freshwater) is a confidently predicted outcome of climate change and these increases are proposed as a significant threat to the biodiversity of freshwater ecosystems (Wallace et al., 2015; Knouft and Ficklin, 2017). These results provide field evidence that predicted warming can directly influence the aquatic invertebrate and benthic diatom community assemblages of tropical streams. Extrapolating these results to riverine ecosystems that have been used in climate modelling assumes a similar biological response. Hot springs such as Talaroo have existed in Queensland for millions of years (Walter et al., 1996), so our results may underestimate the impacts of water temperature rises because taxa in hot spring ecosystems may have evolved greater tolerances to warm water temperatures that those living under ambient temperatures. In addition, water temperatures in this study were often higher than those used in modelling under climate change (see Morrill et al., 2005; Settele et al., 2014).

Temperature modelling under changing climate scenarios for several riverine waterholes in the same region of tropical Queensland, showed that water temperatures increased by approximately $60 \%$ of the predicted air temperature increases (Wallace et al., 2015). While not as large as air temperature increases, the increases in water temperatures were still predicted to have significant effects on riverine biota, especially those with critical thresholds between 28 and $35^{\circ} \mathrm{C}$. Outside of this range the effect of a warming climate on temperature thresholds was determined as minimal (Wallace et al., 2015). In contrast to these previously recorded and modelled temperatures (Wallace et al., 2015), water temperature in the adjacent Einasleigh River has been recorded as reaching levels equivalent to the those analysed in the spring watercourses and on two occasions in the record have reached over $40^{\circ} \mathrm{C}$ (Fig. 4 ).

Water temperatures at these recorded levels of $40^{\circ} \mathrm{C}$ correspond to the potential threshold identified in the relationships with aquatic invertebrate community assemblage, which is characterised by severely reduced taxonomic richness and distinct changes in the community assemblages. The increased probability of extreme heat waves under climate change will make such extreme water temperature episodes more frequent in the future, with possible biodiversity loss consequences. At times where water temperatures in the river are consistently elevated beyond this threshold those species without the ability to disperse to thermal refugia in the river (i.e. deeper pools, shaded habitats and other areas partially protected from increasing temperatures) would likely perish.

However, climate driven increases in water temperature of many groundwater dependent ecosystems such as artesian spring wetlands are likely to be buffered by consistent and stable discharge of water from aquifers not affected by climate patterns.

In conclusion, the water temperature at Talaroo springs gradually drops to ambient conditions as it flows away from the source vents at the top of the spring mound. This natural thermal gradient provided us with a unique opportunity to study the biological community responses to altered temperature regimes. We did find the aquatic invertebrates and benthic diatom communities were strongly related to this water temperature gradient. In addition, a temperature of between 
40 and $42{ }^{\circ} \mathrm{C}$ was identified as a critical threshold for aquatic invertebrate distributions. Nearby riverine locations are already reaching this threshold and under climate change predictions it will be reached more frequently. This indicates the possibility of severe consequences to the aquatic invertebrates in tropical river ecosystems that have consistently increased temperature regimes at these levels. Further detailed understanding of the biological community responses and responses of individual species to increasing water temperature will benefit from targeted laboratory experimentation.

\section{Supplementary Material}

Table S1. The presence of aquatic invertebrates within each sample (X denotes presence).

Table S2. The relative abundance of benthic diatoms within each sample.

The Supplementary Material is available at https://www.kmaejournal.org/10.1051/kmae/2020042/olm.

Acknowledgments. The authors thank the Ewamian Aboriginal Corporation for funding and permitting us to work at the springs and for their support and encouragement to investigate the ecology of this unique wetland. We thank the two anonymous reviewers who provided helpful comments on previous drafts for this manuscript. We also thank the staff at the Ecosciences Chemistry Centre for analysing water samples and Adelaide University for identifying the diatoms collected, in particular Jennie Fluin, John Tibby and Cameron Barr.

\section{References}

Arismendi I, Safeeq M, Dunham JB, Johnson SL. 2014. Can air temperature be used to project influences of climate change on stream temperature? Environ Res Lett 9: 1-12.

Battarbee RW, Jones VJ, Flower RJ, Cameron NG, Bennion H, Carvalho L, Juggins S. 2001. Diatoms. In Smol JP, Birks HJB, Last WM, eds. Tracking Environmental Change Using Lake Sediments. Volume 3: Terrestrial, Algal, and Siliceous Indicators. Dordrecht: Kluwer Academic Publishers, pp. 155-202.

Cantonati M, Komárek J, Montejano G. 2015. Cyanobacteria in ambient springs. Biodivers Conserv 24: 865-888.

Chessman BC, Bate N, Gell PA, Newall P. 2007. A diatom species index for bioassessment of Australian rivers. Mar Freshw Res 58: $542-557$.

Chessman BC, Westhorpe DP, Mitrovic SM, Hardwick L. 2009. Trophic linkages between periphyton and grazing macroinvertebrates in rivers with different levels of catchment development. Hydrobiologia 625: 135-150.

Clarke KR, Somerfield PJ, Chapman MG. 2006. On resemblance measures for ecological studies, including taxonomic dissimilarities and a zero-adjusted Bray-Curtis coefficient for denuded assemblages. J Exp Mar Bio Ecol 330: 55-80.

Dallas H. 2008. Water temperature and riverine ecosystems: an overview of knowledge and approaches for assessing biotic responses, with special reference to South Africa. Water SA 34: 393-404.
De Jong GD, Canton SP, Chadwick JW. 2005. Macroinvertebrates occurring in Sunbeam Hot Springs, an absolutely hot spring in Idaho, USA. J Freshw Ecol 20: 611-613.

Dobbie MJ, Negus P. 2013. Addressing statistical and operational challenges in designing large-scale stream condition surveys. Environ Monit Assess 185: 7231-7243.

Durance I, Ormerod SJ. 2009. Trends in water quality and discharge confound long-term warming effects on river macroinvertebrates. Freshw Biol 54: 388-405.

Foged N. 1978. Diatoms in eastern Australia. Bibl Phycol 41: 1-242.

Foster SE, Soluk DA. 2004. Evaluating exuvia collection as a management tool for the federally endangered Hine's emerald dragonfly, Somatochlora hineana Williamson (Odonata: Cordulidae). Biol Conserv 118: 15-20.

Glazier DS. 2012. Temperature affects food-chain length and macroinvertebrate species richness in spring ecosystems. Freshw Sci 31: 575-585.

Guiry MD. 2020. Rhopalodia musculus (Kützing) O. Müller. AlgaeBase. http://www.algaebase.org/search/species/detail/?spe cies id $=32087$ (accessed January 28, 2020)

John J. 2012. A beginner's guide to diatoms. Königstein: Koeltz Scientific Books, $150 \mathrm{p}$

John J. 2016. Volume 1, The diatom flora of Australia: Diatoms from Stradbroke and Fraser Islands, Australia: Taxonomy and Biogeography. Schmitten-Oberreifenberg: Koeltz Botanical Books, 377 p.

Karanovic I. 2012. Recent freshwater ostracods of the world: Crustacea, Ostracoda, Podocopida. Berlin Heidelberg: SpringerVerlag, 608 p.

Kneitel JM. 2018. Occupancy and environmental responses of habitat specialists and generalists depend on dispersal traits. Ecosphere 9: $1-11$.

Knouft JH, Ficklin DL. 2017. The potential impacts of climate change on biodiversity in flowing freshwater systems. Annu Rev Ecol Evol Syst 48: 111-133.

Krammer K, Lange-Bertalot H. 1986. Bacillariophyceae 1. Teil: Naviculaceae. In Ettl H, Gerloff J, Heynig H, Mollenhauer D, eds. Jena: Gustav Fischer Verlag, 876 p.

Krammer K, Lange-Bertalot H. 1988. Bacillariophyceae. 2. Teil: Bacillariaceae, Epithemiaceae, Surirellaceae. In Ettl H, Gerloff J, Heynig H, Mollenhauer D, eds. Jena: Gustav Fischer Verlag, 596 p.

Krammer K, Lange-Bertalot H. 1991a. Bacillariophyceae. 3. Teil: Centrales, Fragilariaceae, Eunotiaceae. In Ettl H, Gerloff J, Heynig H, Mollenhauer D, eds. Stuttgart, Jena: Gustav Fischer Verlag, 576 p.

Krammer K, Lange-Bertalot H. 1991b. Bacillariophyceae. 4. Teil: Achnanthaceae, Kritische Ergänzungen zu Navicula (Lineolatae) und Gomphonema, Gesamtliteraturverzeichnis Teil 1-4. In Ettl H, Gärtner G, Gerloff J, Heynig H, Mollenhauer D, eds. Stuttgart, Jena: Gustav Fischer Verlag, 437 p.

McGregor GB, Rasmussen JP. 2008. Cyanobacterial composition of microbial mats from an Australian thermal spring: A polyphasic evaluation. FEMS Microbiol Ecol 63: 23-35.

McGregor GB, Sendall BC. 2017. Ewamiania thermalis gen. et sp. nov. (Cyanobacteria, Scytonemataceae), a new cyanobacterium from Talaroo thermal springs, north-eastern Australia. Aust Syst Bot 30: 38-47.

Morrill JC, Bales RC, Conklin MH. 2005. Estimating stream temperature from air temperature: implications for future water quality. J Environ Eng 131: 139-146.

Negus PM, Barr C, Tibby J, McGregor GB, Marshall J, Fluin J. 2019. Subtle variability in water quality structures tropical diatom assemblages in streams of Cape York Peninsula, Australia. Mar Freshw Res 70: 1358-1377. 
Oksanen J, Blanchet FG, Friendly M, Kindt R, Legendre P, McGlinn D, Minchin PR, O'Hara RB, Simpson GL, Solymos P, Henry M, Stevens H, Szoecs E, Wagner H. 2018. vegan: Community Ecology Package. https://cran.r-project.org/package=vegan

Patrick CJ, McGarvey DJ, Larson JH, Cross WF, Allen DC, Benke AC, Brey T, Huryn AD, Jones J, Murphy CA, Ruffing C, Saffarinia P, Whiles MR, Wallace JB, Woodward G. 2019. Precipitation and temperature drive continental-scale patterns in stream invertebrate production. Sci $A d v$ 5: 1-10.

Pentecost A. 2005. Travertine. Berlin, Heidelberg: Springer-Verlag, $445 \mathrm{p}$.

Pentecost A, Jones B, Renaut RW. 2003. What is a hot spring? Can J Earth Sci 40: 1443-1446.

R Core Team. 2017. R: A language and environment for statistical computing.

Rutherford JC, Marsh NA, Davies PM, Bunn SE. 2004. Effects of patchy shade on stream water temperature: How quickly do small streams heat and cool? Mar Freshw Res 55: 737-748.

Settele J, Scholes RJ, Betts RA, Bunn S, Leadley P, Nepstad D, Overpeck JT, Toboada MA. 2014. Terrestrial and inland water systems. In Field CB, Barros VR, Dokken DJ, Mach KJ, Mastrandrea MD, Bilir TE, Chatterjee M, Ebi KL, Estrad YO, Genova RC, Girma B, Kissel ES, Levy AN, MacCracken S, Mastrandrea PR, White LL, eds. Climate Change 2014: Impacts, Adaptation, and Vulnerability. Part A: Global and Sectoral Aspects. Contribution of Working Group II to the Fifth Assessment Report of the Intergovernmental Panel on Climate Change. Cambridge, United Kingdom and New York, NY, USA: Cambridge University Press, pp. 271-359.

Sonneman JA, Sincock AJ, Fluin J, Reid MA, Newall P, Tibby JC, Gell PA. 2000. An illustrated guide to common stream diatom species from temperate Australia. Albury.
Spitale D, Leira M, Angeli N, Cantonati M. 2012a. Environmental classification of springs of the Italian Alps and its consistency across multiple taxonomic groups. Freshw Sci 31: 563-574.

Spitale D, Lencioni V, Cantonati M. 2012b. Relative importance of space and time in determining the biotic structure in the upper part of spring-fed streams. Freshw Sci 31: 586-598.

Sterrenburg FAS, Gordon R, Tiffany MA, Nagy SS. 2007. Diatoms: living in a constructal environment. In: Seckbach J, ed. Algae and cyanobacteria in extreme environments, Dordrecht: Springer, pp. 141-172.

Stetter KO. 1999. Extremeophiles and their adaptation to hot environments. Fed Eur Biochem Soc Lett 452: 22-25.

Taniwaki RH, Piggott JJ, Ferraz SFB, Matthaei CD. 2017. Climate change and multiple stressors in small tropical streams. Hydrobiologia 793: 41-53.

Vannote RL, Sweeney BW. 1980. Geographic analysis of thermal equilibria: a conceptual model for evaluating the effect of natural and modified thermal regimes on aquatic insect communities. $\mathrm{Am}$ Nat 115: 667-695.

Wallace J, Waltham N, Burrows D, Mcjannet D. 2015. The temperature regimes of dry-season waterholes in tropical northern Australia: potential effects on fish refugia. Freshw Sci 6: 663-678.

Walter MR, Desmarais D, Farmer JD, Hinman NW. 1996. Lithofacies and biofacies of mid-paleozoic thermal spring deposits in the Drummond Basin, Queensland, Australia. Palaios 11: 497-518.

Ward JV, Stanford JA. 1982. Thermal response in the evolutionary ecology of aquatic insects. Annu Rev Entomol 27: 97-117.

Wickstrom CE, Castenholtz RW. 1985. Dynamics of cyanobacterial and ostracod interactions in an Oregon hot spring. Ecology 66: 1024-1041.

Zar JH. 1998. Biostatistical analysis. Englewood Cliffs, New Jersey: Prentice Hall.

Cite this article as: Negus PM, Marshall JC, Steward AL, Mcgregor GB, O'Connor RA. 2020. Aquatic biota in hot water: thermal gradients in rheocrene hot spring discharges as analogues for the effects of climate warming. Knowl. Manag. Aquat. Ecosyst., $421,49$. 